\title{
Squash Yellow Leaf Curl Virus: A New Whitefly-Transmitted Poty-Like Virus
}

\author{
A. A. Zouba and M. V. Lopez, Department of Agronomy, Horticulture, Entomology, and Plant Pathology, College \\ of Agriculture; and H. Anger, Department of Pathology, College of Medicine, Sultan Qaboos University, Al-Khod \\ 123, Sultanate of Oman
}

\begin{abstract}
Zouba, A. A., Lopez, M. V., and Anger, H. 1998. Squash yellow leaf curl virus: A new whiteflytransmitted poty-like virus. Plant Dis. 82:475-478.

A severe yellow and leaf curl disease affecting field squash was found in the Batinah region of the Sultanate of Oman. The symptoms appear as small yellow spots, diffuse veinal yellowing, and leaf curling of young leaves. The inciting virus was easily transmitted by mechanical inoculation and by the whitefly Bemisia tabaci in a semi-persistent manner. The host range of the virus was restricted to two cucurbit species. Leaf dip preparations contained few flexuous particles about 700 to $750 \mathrm{~nm}$ long. Pinwheel-like inclusion bodies were observed in thin sections of diseased squash tissues. Serological tests by enzyme-linked immunosorbent assay showed that the virus is serologically related to watermelon mosaic virus-2, but not to zucchini yellow mosaic virus or papaya ring spot virus (watermelon strain). In view of these properties, this virus is considered to be a newly described virus and is tentatively named squash yellow leaf curl virus.
\end{abstract}

Commercial squash crops in the Sultanate of Oman are widely affected by aphidborne viruses, including watermelon mosaic virus-2 (WMV-2), papaya ring spot virus (PRSV-w), zucchini yellow mosaic virus (ZYMV), and cucumber mosaic virus (CMV) (24). Although aphid activities in early fall and late spring are severely checked by extremely high temperatures, squash crops continue to suffer severe losses resulting from virus-like disease epidemics. Large populations of the whitefly Bemisia tabaci (Gennadius) seem to be associated with the occurrence of these diseases.

Whitefly-transmitted cucurbit viruses have been reported from several tropical, subtropical, and temperate areas, including countries in Asia, Europe, and America $(2,4,5,8,9,12,14,16,19,23)$. Bemisia tabaci was reported to transmit at least five cucurbit viruses, including pumpkin yellow mosaic virus (PYMV) from India (5); lettuce infectious yellow virus (LIYV) from California and Arizona $(3,14)$; squash leaf curl virus (SLCV) from the United States, Mexico, and some South American countries (1); and cucurbit yellow stunt disorder (CYSDV) from United Arab Emirates and Spain $(6,16)$. This study was made to provide information on a virus isolated from squash (Cucurbita pepo L.)

Corresponding author: A. A. Zouba

Published with the approval of the College of Agriculture, SQU, as paper number 200597.

Accepted for publication 18 December 1997.

Publication no. D-1998-0304-02R

(C) 1998 The American Phytopathological Society grown in Oman which causes yellowing, leaf curling, and stunting.

\section{MATERIALS AND METHODS}

Source and maintenance of the virus and whitefly. The virus isolate used in this study was obtained from commercial squash fields in the Batinah region. Collected leaf samples were placed in a small plastic bottle of an insect aspirator. Nonviruliferous whiteflies, maintained on eggplant in an insect-proof cage, were sucked into the bottle and allowed to feed for $24 \mathrm{~h}$.

Whiteflies then were transferred to young squash seedlings for $48 \mathrm{~h}$. Whiteflies were removed and plants were maintained in a growth chamber at 28 to $30^{\circ} \mathrm{C}$. Plants showing yellow spotting, veinal yellowing, and leaf curling were used as a virus source for this study.

Mechanical transmission. Young symptomatic leaves were ground in $0.2 \mathrm{M}$ potassium phosphate buffer ( $\mathrm{pH} 7)$ containing $0.02 \mathrm{M}$ sodium sulfite and Carborundum as an abrasive. The extract (1:2 $\mathrm{wt} / \mathrm{vol}$ ) was rubbed onto squash cotyledons and/or true leaves. Test and control plants (rubbed with buffer only) were kept in a growth chamber at 28 to $30^{\circ} \mathrm{C}$.

Host range. Seeds of test plants were sown in 15-cm-diameter pots in insect-proof cages in the greenhouse. Before inoculating, plants at 2- to 3-leaf stage were thinned to 3 plants/pot and mechanically inoculated as described above. The experimental host range study included 28 plant species from 10 families. A minimum of 9 seedlings from each species were tested. After 3 weeks, plants were tested for infection by retroinoculation to squash seedlings.

Virus-vector relationships. The minimum acquisition feeding period was determined by allowing non-viruliferous whiteflies to feed on infected squash leaves for $15 \mathrm{~min}, 30 \mathrm{~min}$, or $1,2,4,8,16$, or 24 $\mathrm{h}$. Whiteflies in groups of 25 were transferred to 9 healthy squash seedlings per acquisition time for a feeding inoculation period of $24 \mathrm{~h}$. Plants were sprayed with the insecticide endosulfan to eliminate the vector and placed in a growth chamber. The experiment was repeated four times using a total of 36 test seedlings per treatment. The minimum transmission feeding period was determined by allowing nonviruliferous whiteflies to feed on a virus source for 2 or $24 \mathrm{~h}$. The whiteflies were then transferred in groups of 25 on each of 9 test seedlings for transmission feeding periods of $15 \mathrm{~min}, 30 \mathrm{~min}$, or 1, 2, 4, 10, 15 , or $24 \mathrm{~h}$. The experiment was repeated four times using a total of 36 test plants. The ability of viruliferous vectors to retain the virus (virus persistence in vector) was determined by allowing whiteflies to feed on a virus source for $24 \mathrm{~h}$, then transferring the whiteflies daily in groups of 20 on each of 12 healthy squash seedlings for 8 consecutive days.

Electron microscopy. Drops of sap were collected on the surface of formvar/carbon-coated 400 mesh copper grids by touching the coated surface of the grid on to the cut face of a leaf vein. The secreted fluid was allowed to sit on the grid for 2 min before it was drawn off the grid with a piece of filter paper and replaced with a drop of $3 \%$ phosphotungstic acid. The acid was left for $2 \mathrm{~min}$ and removed in the same way. The grid was allowed to dry, and then was examined in a Zeiss EM900 Electron Microscope at magnifications of 30,000 to $50,000 \times$ using $80 \mathrm{KV}$. For ultrathin sectioning, small portions of infected leaves were fixed in $2.5 \%$ phosphate-buffered gluteraldehyde for $2 \mathrm{~h}$, washed $2 \times 10 \mathrm{~min}$ in phosphate buffer, followed by secondary fixation in $1 \%$ aqueous osmium tetroxide for $2 \mathrm{~h}$. Following washing $2 \times 5 \mathrm{~min}$ in distilled water, specimens were dehydrated in ascending grades of acetone to propylene oxide. The specimens were impregnated and embedded in Araldite CY212 (AGAR Scientific). Ultrathin sections $(80 \mathrm{~nm})$ were cut on a Reichert-Jung Ultracut E ultramicrotome using a diamond knife. Sections were stained with a conventional Uranyl Acetate-Lead Citrate protocol (20) and examined in either a Zeiss EM900 or JEOL 1200EX electron microscope using a magnification range of 3,000 to $30,000 \times$ and accelerating voltage of $80 \mathrm{KV}$. 
Serological assays. The serological relationships with members of the potyvirus group commonly associated with cucurbits was determined following the observation of poty-like virus particles in the electron microscope. Diseased squash tissue was tested for cross reaction to WMV-2, ZYMV, and PRSW-w polyclonal antibodies by enzyme-linked immunosorbent assay (ELISA) (7,18 ). The diagnostic kits for ELISA against these viruses were obtained from Agdia Inc. (Indiana).

\section{RESULTS}

Mechanical inoculation and symptoms. When diseased squash leaves were used as a virus source for mechanical inoculation, the virus was easily transmitted to squash seedlings. Symptoms developed 4 to 5 days following inoculation. Early symptoms were apparent on the newly formed leaves as small yellow spots (Fig. 1). Subsequent leaves showed yellow spotting, vein chlorosis, upward curling, and brittleness. Infected plants became

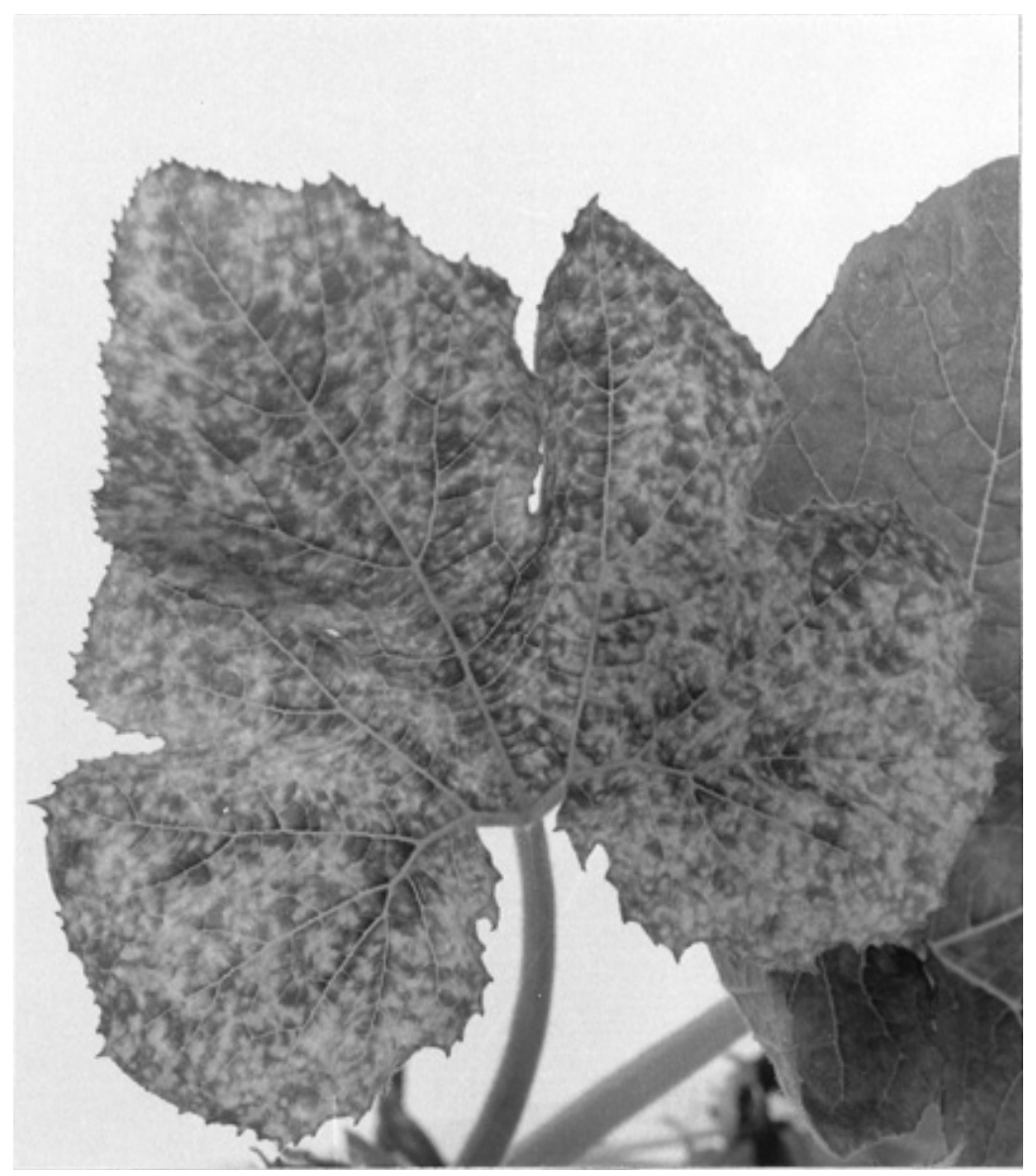

Fig. 1. Squash leaf mechanically infected with squash yellow leaf curl virus, showing characteristic symptoms of yellow spotting and veinal yellowing.

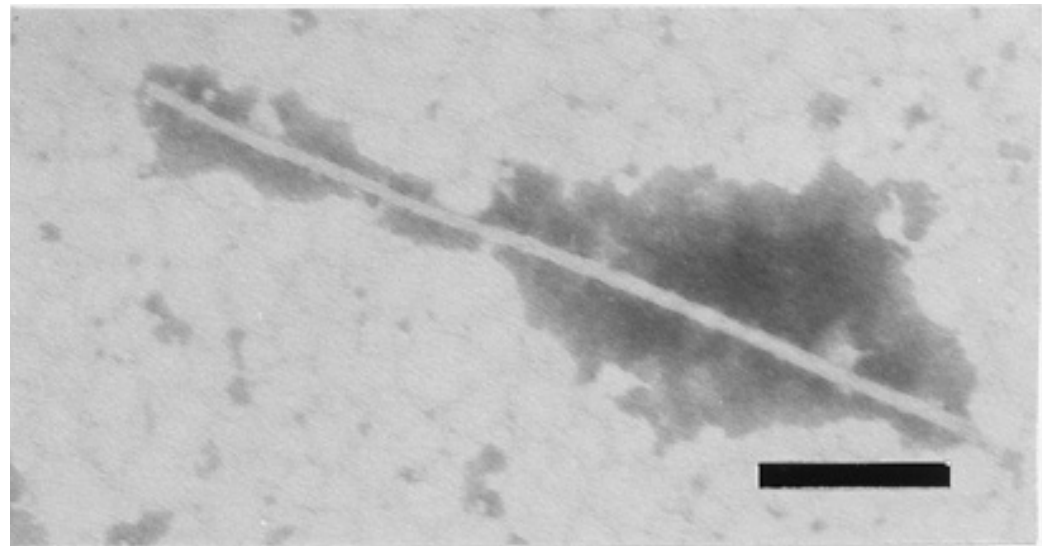

Fig. 2. Electron micrograph of a squash yellow leaf curl virus particle stained with $3 \%$ phosphotungstic acid in leaf dip preparation from mechanically infected squash plant. Bar represents $0.15 \mu \mathrm{m}$. severely stunted and did not produce fruit. When mechanically inoculated squash plants were used as a virus source for whitefly transmission to healthy plants, similar symptoms developed 5 to 6 days after inoculation.

Host range. Among the plant species tested, symptoms developed only in the following cucurbit species: Cucurbita pepo L. (squash and pumpkin) and Luffa aegyptiaca Mill. (sponge gourd). Infected pumpkin and sponge gourd plants showed vein clearing and systemic yellow spotting on the newly formed leaves; however, plants did not show leaf curling or severe stunting, which were present in squash. No symptoms were observed in the following plant species: Asteraceae, Helianthus annuus L.; Chenopodiaceae, Beta vulgaris L. and Chenopodium quinoa L.; Convolvulaceae, Ipomoea batatas (L.) Lam.; Cruciferes, Brassica oleracea var. botrytis L., B. rapa L., and Raphanus sativus L.; $\mathrm{Cu}-$ curbitaceae, Citrullus colocynthis Thunb. C. lanatus (Thunb.) Matsum \& Nakai, Cucumis melo L., C. sativus L., and Lagenaria siceraria Standl.; Gramineae, Hordeum vulgare L.; Leguminoseae, Arachis hypogaea L., Cicer arietinum L., Lens culinaris Medic., Phaseolus aureus Roxb., P. vulgaris L., Pisum sativum L., and Vigna unguiculata L.; Malvceae, Hibiscus esculentus L.; Solanaceae, Capsicum annuum L., Lycopersicon esculentum Mill., Nicotiana benthamiana L., $N$. rustica L., $N$. tabacum 'xanthi' L., and Physalis floridana Rybd.; and Umbellifereae, Daucus carota $\mathrm{L}$.

Minimum acquisition feeding period. The minimum feeding time for whiteflies to become viruliferous was $1 \mathrm{~h}$, after which a transmission rate of $11.1 \%( \pm 0.0)$ was observed. The transmission efficiency of the vector increased with increasing feeding time. The percentage of transmission after acquisition feeding periods of $2,4,8$, 16 , or $24 \mathrm{~h}$ was $27.8( \pm 6.4), 69.4( \pm 5.5)$, 88.9 ( \pm 9.0$), 94.4( \pm 6.4)$, and $97.2( \pm 7.8)$, respectively. Values in parentheses represent standard deviation.

Minimum transmission feeding period. When whiteflies were fed on a virus source for $24 \mathrm{~h}$ and then transferred to healthy test seedlings for $15 \mathrm{~min}, 30 \mathrm{~min}$, or $1,2,4,10,15$, or $24 \mathrm{~h}$, the average percent transmission obtained was $0,0,30.5$ $( \pm 9.0), \quad 36.1 \quad( \pm 5.5), \quad 44.4 \quad( \pm 9.0), \quad 77.7$ $( \pm 12.8), 91.6( \pm 10.6)$, and $94.5( \pm 11.1)$, respectively. When whiteflies were fed for only $2 \mathrm{~h}$ on the virus source and then transferred to healthy plants for $15 \mathrm{~min}, 30 \mathrm{~min}$, or $1,2,4,10,15$, or $24 \mathrm{~h}$, the average percentage transmission was $0,0,11.1( \pm 9.0)$, 19.5 ( \pm 5.5$), 27.8$ ( \pm 6.4$), 38.8( \pm 11.1), 47.2$ $( \pm 10.6)$, and $52.8( \pm 11.1)$, respectively. The results of the experiments suggested a minimum transmission period for viruliferous whiteflies to transmit the virus of 1 $\mathrm{h}$, with a latent period in the vector, if any, of less than $1 \mathrm{~h}$. 
The maximum virus retention by the vector. Whiteflies fed on diseased squash for $24 \mathrm{~h}$ retained the ability to transmit the virus for a maximum period of 5 days.

Electron microscopy. Sap from squash infected by the virus under study, designated squash yellow leaf curl virus (SYLCV), contained very few flexuous, rod-shaped particles approximately 700 to $750 \mathrm{~nm}$ long (Fig. 2). Cytopathological studies have shown bundles of flexuous rod-shaped particles in the sieve element (Fig. 3A). Pinwheel-like inclusion bodies were observed in the cytoplasm of vascular parenchyma cells (Fig. 3B).

Serology. Polyclonal antibodies specific to WMV-2 reacted positively with SYLCV in ELISA tests. This cross-reaction was confirmed by using another source of WMV-2 antibodies obtained from Adgen Diagnostic Systems (Scotland, UK). No reactions were obtained when the virus was tested against antibodies to ZYMV or PRSV-w.

\section{DISCUSSION}

Symptoms caused by the virus under study are not very different from those induced by other whitefly-transmitted filamentous viruses reported on cucurbits. These symptoms included yellow spots, interveinal yellowing, brittleness, and leaf curling $(10,13)$. However, the virus can be easily differentiated by its particle size, cytopathological effects, mode of transmission, and host range. Filamentous viruses that are transmitted by whiteflies have been shown to belong to at least four distinct groups, including closteroviruses, potyviruses, carlaviruses, and DNA-containing rod-shaped viruses (13). The particle size, the presence of pinwheel-like inclusion bodies, the serological relationships with WMV-2, and the capacity of being mechanically transmitted suggest a similarity of SYLCV to other members of the potyvirus group. (15). The sweet potato mild mottle virus (SPMMV) (17) seems to be the only described whitefly-transmitted virus with poty-like virus properties. SPMMV has particles of approximately 750 and $950 \mathrm{~nm}$ and produces pinwheellike inclusion bodies in infected cells, but no serological relationships were observed with other potyvirus members, including WMV-2. The SYLCV reported here is different from SPMMV by its host range and its relationship with the insect vector. The host range of SPMMV includes several plant species from several families, while in the case of SYLCV only two cucurbit species out of 28 plant species from 10 families tested were found to be susceptible. The minimum acquisition feeding period was demonstrated to be 5 days for SPMMV and only $1 \mathrm{~h}$ for SYLCV. Although SYLCV is serologically related to the aphid-borne WMV-2, they clearly differ by their host range, symptoms, and vectors (22). Symptoms caused by SYLCV are similar to those induced by whiteflytransmitted clostero-like viruses $(10,13)$; however, these can be easily distinguished by their particle length, cytopathological effects, host range, and mode of transmission. Although rod-shaped DNA-containing virus particles described by Cohen and
Nitzany $(9,21)$ are transmitted by $B$. tabaci and also by sap inoculation, this virus differs from SYLCV in symptoms and host range. The nucleic acid nature of SYLCV has not been identified. Based on the present study, SYLCV appears to have several characteristics that distinguish it from
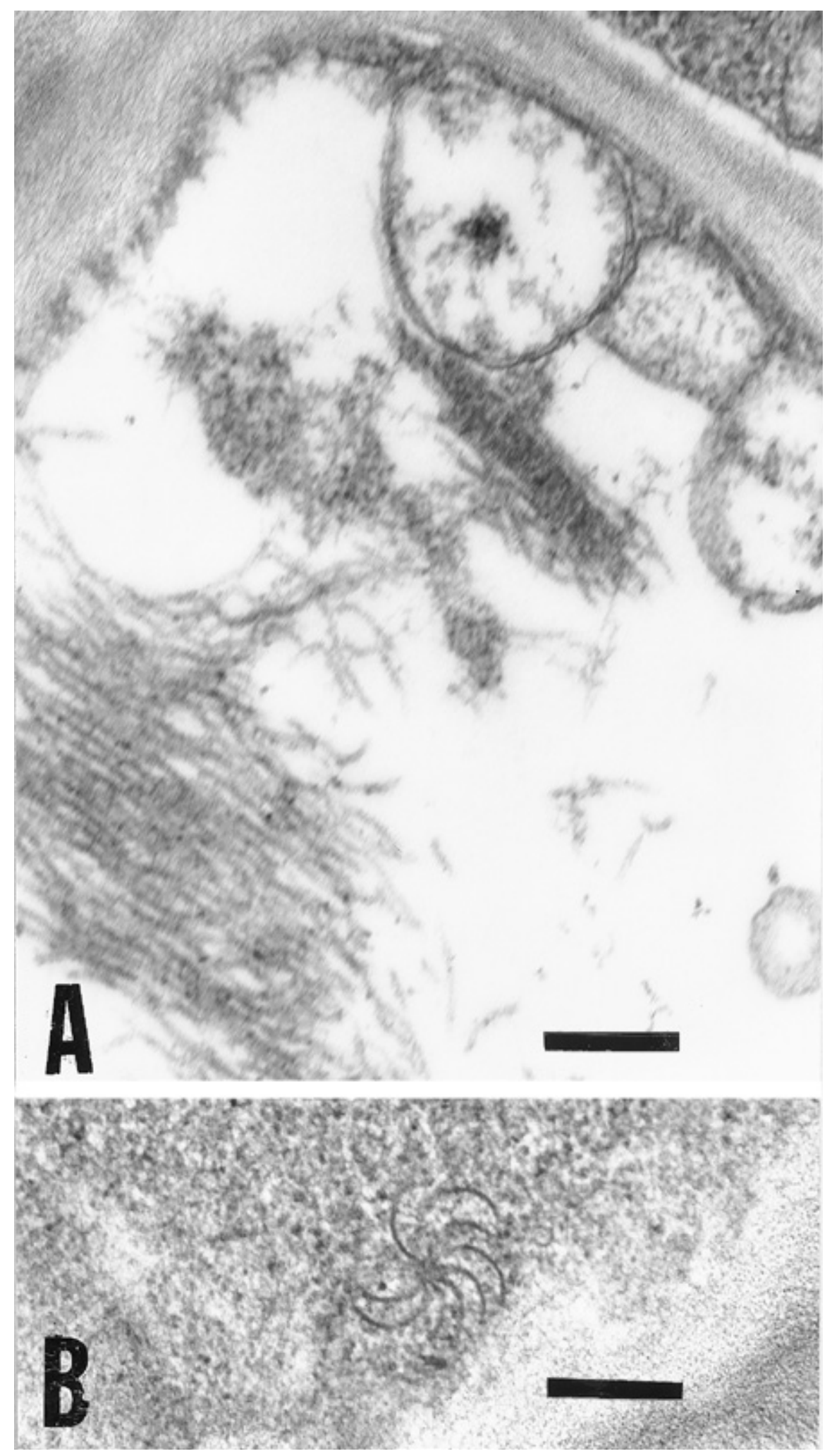

Fig. 3. Thin section of squash leaf mechanically infected with squash yellow leaf curl virus, negatively stained with Uranyl acetate-lead-citrate. (A) Bundle of flexuous rod-shaped particles in the sieve elements. (B) Pinwheel inclusion body in vascular parenchyma cells. Bar represents $0.25 \mu \mathrm{m}$. 
other whitefly-transmitted viruses. Therefore, we have tentatively named it squash yellow leaf curl virus.

\section{LITERATURE CITED}

1. Brown, J. K. 1990. An update on the whitefly-transmitted geminiviruses in the Americas and the Caribbean Basin. FAO Plant Prot. Bull. 39:5-23.

2. Brown, J. K., and Nelson, M. R. 1984. Two whitefly-transmitted viruses of melons in the Southwest. (Abstr.) Phytopathology 74:1136.

3. Brown, J. K., and Nelson, M. R. 1986. Whitefly-borne viruses of melons and lettuce in Arizona. Phytopathology 76:236-239.

4. Brown, J. K., and Nelson, M. R. 1989. Characterization of watermelon curly mottle virus, a geminivirus which is similar to, but biologically distinct from, squash leaf curl virus. Ann. Appl. Biol. 115:243-252.

5. Capoor, S. P., and Ahmed, R. U. 1975. Yellow Vein Mosaic disease of field pumpkin and its relationship with the vector, Bemisia tabaci. Indian Phytopathol. 28:241-246.

6. Celix, A., Lopez Sese, A., Almarza, N., Gomez-Guillamon, M. L., and RodriguezCererzo, E. 1996. Characterization of cucurbit yellow stunting disorder virus, a Bemisia tabaci-transmitted closterovirus. Phytopathology 86:1370-1376.

7. Clark, M. E., and Adams, A. N. 1977. Characteristics of the microplate method enzymelinked immunosorbent assay for the detection of plant viruses. J. Gen. Virol. 34:475-483.
8. Cohen, S., Duffus, J. E., Larson, R. C., and Flock, R. A. 1983. Purification, serology and vector relationships of squash leaf curl virus, a whitefly-transmitted geminivirus. Phytopathology 73:1669-1673.

9. Cohen, S., and Nitzany, F. E. 1960. A whitefly-transmitted virus of cucurbits in Israel. Phytopathol. Mediterr. 1:44-46.

10. Conti Maurizio, A. 1994. Whiteflies other than Bemisia tabaci as vectors of plant viruses. Arabian J. Plant Prot. 12:121-126.

11. Costa, A. S. 1986. Whitefly-transmitted diseases. Annu. Rev. Phytopathol. 14:429-449.

12. Duffus, J. E. 1965. Beet pseudo-yellows virus, transmitted by the greenhouse whitefly (Trialeurodes vaporarium). Phytopathology 55:450-453.

13. Duffus, J. E. 1994. Diseases vectored by whiteflies. Etiology, ecology, geographical distribution and possible control measures. Arabian J. Plant Prot. 12:143-148.

14. Duffus, J. E., Larsen, R. L., and Liu, H. Y. 1986. Lettuce infectious yellow virus - A new type of whitefly transmitted virus. Phytopathology 76:97-100.

15. Francks, R. I. B., Milne, R. G., and Hatta, T. 1985. Atlas of Plant Viruses, Vol. II. CRC Press, Inc. Boca Raton, FL.

16. Hassan, A. A., and Duffus, J. E. 1991. A review of a yellowing and stunting disorder of cucurbits in the United Arab Emirates. Emir. J. Agric. Sci. 2:1-16.

17. Hollings, M., Stone, O. M., and Bock, K. R. 1976. Purification and properties of sweet potato mild mottle virus, a whitefly-borne virus from sweet potato in East Africa. Ann Appl. Biol. 82:511-528.

18. Lommel, S. A., McCain, A. H., and Morris, T. J. 1982. Evaluation of indirect enzyme-linked immunosorbent assay for the detection of plant viruses. Phytopathology 71:1019-1022.

19. Lot, H., Delecolle, B., and Lecog, H. 1983. A whitefly transmitted virus causing musk melon yellows in France. Acta Hortic. 12:175-182.

20. Reynolds, E. S. 1963. The use of lead citrate at high $\mathrm{pH}$ as an electron-opaque stain in electron microscopy. J. Cell Biol. 17:208-212.

21. Sela, I., Assouline, I., Tanne, E., Cohen, S. and Marco, S. 1980. Isolation and characterization of a rod-shaped whitefly transmissible, DNA-containing plant virus. Phytopathology 70:226-228.

22. Van Regenmortel, M. H. V. 1971. Watermelon mosaic virus No.63. Descriptions of plant viruses. Commonw. Mycol. Inst./Assoc. Appl. Biol., Kew, Surrey, Eng.

23. Yamashita, S., Doi, Y., Yora, K., and Yashino, M. 1979. Cucumber yellows virus: its transmission by the greenhouse whitefly, Trialeurodes vapororium (Westwood), and the yellowing disease of cucumber and muskmelon caused by the virus. Ann. Phytopathol. Soc. Jpn. 45:484-496.

24. Zouba, A. A., Khan, A. J., and Al-Maqbaly, Y. M. 1977. Survey of virus diseases of cucurbits in the Batinash Region of the Sultanate of Oman. Arabian J. Plant Prot. 15:43-46. 